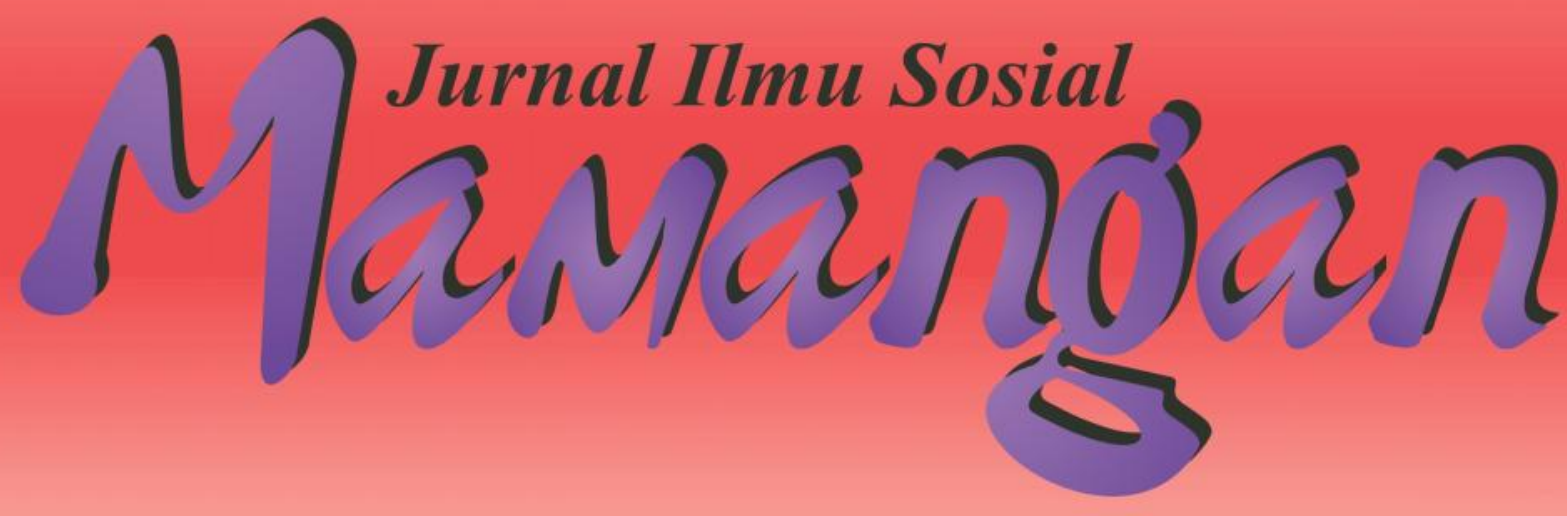

Peran Perantau Terhadap Pembangunan Di Jorong Galogandang, Nagari III Koto Kec. Rambatan, Kab. Tanah Datar Vivi Emita, Zusmelia \& Marleni

Julo-Julo Tani Buruh Perempuan Jorong Patamuan, Nagari Talu Kecamatan Talamu Kab. Pasaman Barat Sriwahyuni, Zusmelia \& Delmira Syafirini

Dari Petani Ke Penambang; Perubahan Sosial Ekonomi Di Jorong Koto Panjang, Nagari Limo Koto, Kabupaten Sijunjung

Melta Ardila Sari, Ardi Abbas \& Darmairal Rahmad

Strategi Masyarakat Multikultural Pasaman Barat Menghindari Konflik

Elly Kristin Debora, Dian Kurnia Anggreta \& Faishal Yasin

Konflik Sopir PO. Mitra Kencana Vs Pengemudi Betor di Air Bangis, Kab. Pasaman Barat

Helma Frida, Witrianto \& ZusneliZubir

Konflik Tanah Ulayat Antara Kamanakan Malakok VS Niniak Mamak Suku Tobo Di Nagari Padang Laweh, Kec. Koto VII, Kab. Sijunjung Welda Ningsih, Dian Kurnia Anggreta \& Rinel Fitlayeni 


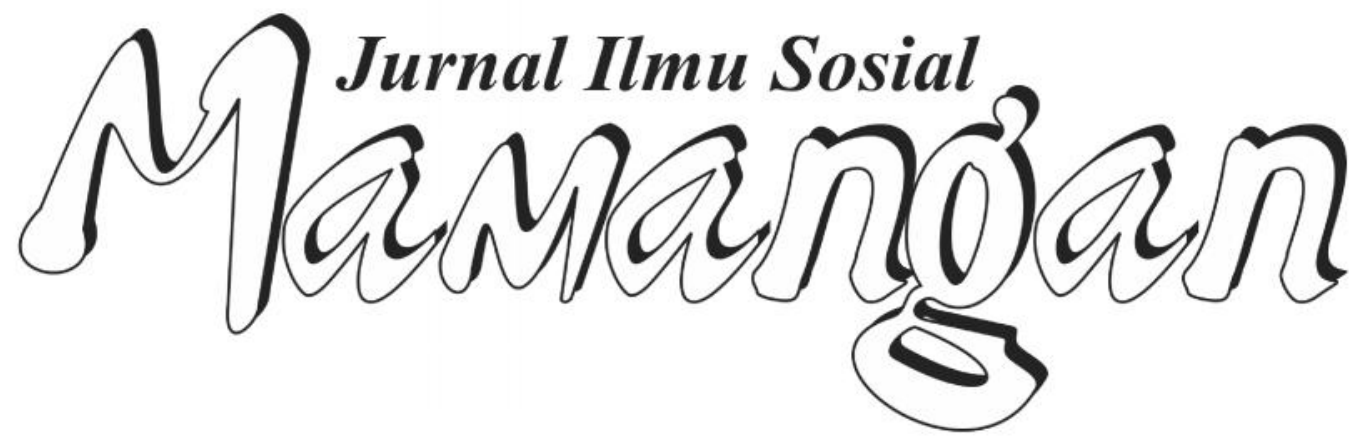




\section{Mitra Bestari}

Prof. Dr. Afrizal, MA. (FISIP, Unand Padang)

Dr. A. Latief Wiyata, M. Si. (Universitas Jember, Jember)

Prof. Dr. Badaruddin, M. Si. (FISIP, USU Medan)

Dr. Fikarwin Zuska, M. Si. (FISIP, USU Medan)

Nurus Shalihin, M. Si., Ph.D. (Fak. Ushuluddin IAIN Imam Bonjol Padang)

Dr. Semiarto A. Purwanto, M. Si. (FISIP, UI Jakarta)

Dr. Wahyu Wibowo, M. Si. (Universitas Nasional, Jakarta)

\section{Dewan Redaksi}

Dr. Zusmelia, M. Si.

Dr. Maihasni, M. Si.

Adiyalmon, S. Ag., M. Pd.

Firdaus, S. Sos., M. Si.

\section{Pemimpin Redaksi}

Firdaus, S. Sos., M. Si.

\section{Anggota Redaksi}

Dian Kurnia Anggreta, S. Sos., M. Si.

Rinel Fitlayeni, S. Sos., MA.

Surya Prahara, SH.

ISSN: 2301-8496

\section{Alamat Redaksi:}

Laboratorium Program Studi Pendidikan Sosiologi, STKIP PGRI Padang

Jl. Gunung Pangilun, Padang

Email: redaksimamangan@yahoo.com

Penerbit :

Program Studi Pendidikan Sosiologi, STKIP PGRI Padang

\section{Contac person :}

Firdaus (Hp. 085263881221/Email : daus gila@yahoo.com) 


\section{DAFTAR ISI}

Peran Perantau Terhadap Pembangunan Di Jorong Galogandang, Nagari III Koto Kec. Rambatan, Kab. Tanah Datar

Vivi Emita, Zusmelia \& Marleni

Julo-Julo Tani Buruh Perempuan Jorong Patamuan, Nagari Talu Kecamatan Talamu Kab. Pasaman Barat

Sriwahyuni, Zusmelia \& Delmira Syafirini

Dari Petani Ke Penambang; Perubahan Sosial Ekonomi Di Jorong Koto Panjang, Nagari Limo Koto, Kabupaten Sijunjung

Melta Ardila Sari, Ardi Abbas \& Darmairal Rahmad

Strategi Masyarakat Multikultural Pasaman Barat Menghindari Konflik

Elly Kristin Debora, Dian Kurnia Anggreta \& Faishal Yasin

Konflik Sopir P0. Mitra Kencana Vs Pengemudi Betor di Air Bangis, Kab. Pasaman Barat

Helma Frida, Witrianto \& Zusneli Zubir

Konflik Tanah Ulayat Antara Kamanakan Malakok VS Niniak Mamak Suku Tobo Di Nagari Padang Laweh, Kec. Koto VII, Kab. Sijunjung Welda Ningsih, Dian Kurnia Anggreta \& Rinel Fitlayeni. 


\title{
PERAN PERANTAU TERHADAP PEMBANGUNAN DI JORONG GALOGANDANG, NAGARI III KOTO KEC. RAMBATAN KAB. TANAH DATAR
}

\author{
Vivi Emita, Zusmelia \& Marleni \\ Sekolah Tinggi Keguruan dan Ilmu Pendidikan (STKIP) PGRI Sumatera Barat
}

\begin{abstract}
Marantau is a tradition of Minangkabau society. Likewise with Galogandang society, apart from wander into a tradition of economic factors and natural conditions as well as a stimulus for people to wander Galogandang. Factors livelihood homogeneous and inadequate fulfillment of everyday life so that people Galogandang 70\% Barada was overseas. Analysis in this study using the theory of rational choice. The approach used is qualitative approach with descriptive method. Informants in this study is masayarkat and strangers Galogandang. Data collection techniques, observation, interviews, and documents. Analysis of the data used in this research is the analysis of qualitative data that is interactive analysis proposed by Miles and Huberman. From the results of this study concluded that the role of migrants to the development of Nagari in Jorong Galogandang can be divided into two parts, namely, the development of physically seen an increase in development such as the construction of the Grand Mosque, mosque, TPA, bakl sources of clean water, and nonphysical looks Scholarships the education of children of school achievement. Viewed wander impact on socio-economic, such as construction of houses is getting better, and people's incomes Galogandang that no longer depend on pertaniann only.
\end{abstract}

\section{Keywords : Perantau, Development, Participation}

\begin{abstract}
ABSTRAK
Merantau merupakan suatu tradisi masyarakat Minangkabau. Demikian halnya dengan masyarakat Galogandang, selain dari merantau menjadi suatu tradisi faktor ekonomi dan keadaan alam juga sebagai pendorong bagi masyarakat Galogandang untuk merantau. Faktor mata pencaharian hidup yang bersifat homogen dan kurang mencukupi pemenuhan kebutuhan hidup sehari-hari sehingga masyarakat Galogandang 70\% barada di rantau. Analisa pada penelitian ini menggunakan teori pilihan rasional. Pendekatan yang digunakan adalah pendekatan kualitatif dengan metode penelitian deskriptif. Informan pada penelitian ini adalah masyarakat dan perantau Galogandang. Teknik pengumpulan data, observasi lapangan, wawancara, dan dokumen. Analisis data yang digunakan pada penelitian ini adalah analisis data kualitatif yaitu analisis interaktif yang dikemukakan oleh Miles dan Huberman. Dari hasil penelitian dapat disimpulkan, bahwa peran perantau terhadap pembangunan Nagari di Jorong Galogandang dapat dibagi atas dua bagian yaitu, pembangunan dari segi fisik terlihat peningkatan pembangunan seperti pembangunan Mesjid, mushala, TPA, bak sumber air bersih, dan non fisik terlihat dengan adanya beasiswa pendidikan anak-anak yang sekolah berprestasi. Dilihat dampak merantau terhadap sosial ekonomi masyarakat seperti pembangunan rumah penduduk yang semakin bagus, dan pendapatan masyarakat Galogandang yang tidak lagi bergantung pada pertanian saja.
\end{abstract}

Kata Kunci: Perantau, Pembangunan, Partisipasi 


\section{PENDAHULUAN}

Masyarakat Minangkabau memiliki suatu tradisi yang dikenal dengan merantau. Merantau pada masyarakat Minangkabau pada dasarnya banyak dilakukan kaum lakilaki, dimana sesuai dengan pepatah Minangkabau yaitu "karatau madang dihulu, babuah babungo balun, merantau bujang dahulu dirumah paguno balun" (Naim 1984), maksud dari pribahasa ini adalah laki-laki di Minangkabau merasa lebih baik pergi merantau meninggalkan kampung halaman karena merasa belum diperlukan dirumahnya. Pepatah tersebut juga merupakan suatu pendorong bagi lakilaki Minangkabau untuk pergi merantau, guna meraih keberhasilan secara materi.

Faktor lain yang mendorong suatu masyarakat merantau adalah faktor ekonomi yang cenderung semakin banyak pengeluaran dengan membutuhkan pemasukan yang lebih besar dari sekedar untuk makan sehari-hari saja, faktor mata pencaharian hidup yang bersifat homogen yaitu bertani, dan faktor ilmu pengetahuan yang berbeda untuk melakukan suatu pekerjaan, karena pekerjaan didaerah asal tidak memiliki potensi lagi dalam pemenuhan kebutuhan hidup. Sehingga muncul suatu ide dalam bentuk prilaku untuk mereka dalam menyikapi keterbatasan potensi SDA (Sumber Daya Alam) dan lapangan kerja didaerah asal dengan cara merantau yang biasanya identik dengan menjadi pedagang di rantau. Karena menurut mereka dengan cara merantau maka akan mengubah perekonomian keluarga kelak lebih baik.

Beberapa faktor tersebut merupakan faktor pendorong secara umum, dan saling terkait satu sama lain. Seperti antara faktor ekonomi dan faktor ilmu pengetahuan yang saling berkaitan. Kedua faktor tersebut merupakan faktor yang dominan sebagai sesuatu pendorong masyarakat untuk merantau. Sesuai dengan filosofis hidup merantau yaitu dima bumi dipijak, disinan langik di junjuang (maksud dari peribahasa tersebut adalah bagaiman masyarakat Minangkabau mampu menyesuaikan diri dengan lingkungannya di rantau) filosofis inilah yang selalu dibawa dan dijadikan acuan dalam hidup didaerah perantauan.

Selain dari faktor pendorong dari daerah asal, ada juga faktor penarik dari kota seperti peluang kerja yang besar dan beragam. Kondisi didaerah asal kerap kali menjadi alasan seseorang untuk melakukan suatu tradisi merantau, apalagi setelah mendengar orang yang pergi sebelumnya berhasil dengan mata pencaharian yang baru di rantau. Hal tersebut menyebabkan daerah asal menjadi sunyi karena sebagian besar dari masyarakat juga pergi merantau.

Berdasarkan penelitian yang penulis lakukan didaerah jorong Galogandang, sebagian besar dari masyarakat hidup di rantau. Berdasarkan data awal yang penulis dapat dari wali nagari pada umumnya perantau tersebar diberbagai daerah, baik diluar provinsi Sumatera Barat maupun yang merantau dapat dikatakan telah berhasil. Hal tersebut dapat dilihat dari beberapa indikator seperti sebagai berikut, seperti sudah memiliki kendaraan pribadi, sudah mampu untuk menunaikan ibadah haji, sudah memiliki usaha yang semakin maju seperti tidak hanya berdagang saja tetapi ada yang sudah mempunyai rumah untuk disewakan. Mereka juga ikut membangun kampung atau nagarinya dengan menyumbang atau mengirim uang untuk biaya pembangunan.

Sangat jelas di sini dilihat pentingnya peran perantau untuk pembangunan daerahnya, karena mereka merupakan bagian dari yang memiliki tanggung jawab untuk melakukan suatu perencanaan demi kemajuan daerahnya. Disini sama halnya dengan masyarakat nagari Galogandang yang secara bersama memutuskan untuk sama-sama membangun nagarinya dengan cara menginvestasikan materil kepada pengurus masing-masing bagian yang akan melakukan pembangunan yang menjabat agar melakukan suatu gerak pembangunan melalui tangan donatur dari rantau. Ketika pembangunan tersebut yang memiliki daya guna atau bermanfaat bagi masyarakat yang masih menetap dikampung halamannya. Setiap pembangunan yang dilakukan juga harus diperhitungkan fungsinya, sehingga peran perantau tadi turut membantu pembangunan nagari asal memiliki suatu hubungan kerja sama antara perantau dengan pemerintah daerah. Peran perantau terhadap pembangunan di Galogandang dapat terlihat dari berbagai perkembangan dan perbaikan fasilitas umum seperti mesjid, sumber air bersih, lapangan sepak 
bola dan beasiswa pendidikan. Pembangunan yang telah selesai akan diberi sebuah papan nama daerah rantau mana yang membangunnya. Selain itu, ada juga sumbangan perantau secara individu seperti menyumbang ke mesjid pada saat lebaran. Biasanya sumbangan tersebut dikirim melalui kelurga yang berada dikampung, dengan menyebutkan nama perantau dan jumlah uangnya.

Perantau Galogandang yang berada didaerah rantau begitu akrab dan masih tetap mimiliki tujuan utama yaitu memajukan pembangunan Nagari. Keakraban tersebut dapat dilihat dengan adanya organisasi perantau Galogandang disetiap daerah perantau. Masing-masing daerah rantau memiliki nama persatuan yang memiliki nama persatuan yang akan menjadi simbol nama untuk mewakili masing-masing kelompok daerah rantau. Nama persatuan tersebut ialah IKAPGA, arti dari IKAPGA itu sendiri ialah 'Ikatan Keluarga Perantau Galogandang'. Untuk nama IKAPGA Pasaman dan IKAPGA JAYA karena yang paling banyak perantau Galogandang berada didaerah Pasaman dan Jakarta. Pembentukan organisasi tersebut untuk memperkuat rasa kekeluargaan di rantau, karena dengan adanya persatuan organisasi dapat mempermudah dalam mengkoordinir perantau yang berasal dari Galogandang. Dinamika kehidupan masyarakat Galogandang tersebut, menarik perhatian penulis untuk melakukan penelitian lebih lanjut tentang peran perantau terhadap pembangunan di Jorong Galogandang Nagari III Koto Kecamatan Rambatan Kabupaten Tanah Datar.

\section{STUDI RELEVAN}

Berdasarkan studi kepustakaan yang penulis lakukan, penelitian yang relavan dengan penelitian yang akan penulis lakukan dengan penelitian yang dilakukan oleh (Fitriasi 2011) yang melakukan peneltian dengan judul kehidupan sosial ekonomi perantau Minangkabau di kota Tarutung Kabupaten Tapanuli Utara. Hasil penelitiannya menunjukkan bahwa ada beberapa faktor yang mempengaruhi Tarutung Kabupaten Tapanuli Utara. Hasil penelitiannya menunjukkan bahwa ada beberapa faktor yang mempengaruhi orang Minangkabau datang ke Tarutung, yaitu faktor sosial ekonomi dan faktor pekerjaan. Perantau Minangkabau di Tarutung tidak hanya bekerja pada sektor dagang saja, tetapi juga ada yang bekerja pada pemerintahan Taruntung.

Tulisan lain yang juga relevan dengan penelitian yang dilakukan ini yaitu Amitri Yulia (2007) yang berjudul " Kehidupan Sosial Ekonomi Perantau Minangkabau dikota Pekanbaru studi kasus kecamatan Sukajadi 2000". Skripsi ini mengkaji tentang kehidupan sosial ekonomi prantau Minangkabau di Pekanbaru khususnya kecamatan Sukajadi. Hasil penelitian ini menunjukkan bahwa kehidupan sosial ekonomi perantau Minangkabau memiliki pekerjaan dan penghasilan yang beragam.

Selain itu, tulisan yang juga relevan dengan penelitian ini adalah Devi Yulia (2009) yang berjudul "Kepedulian perantau terhadap pembangunan kampung halaman, studi kasus : nagari Saniang Baka Kecamatan X Koto Singkarak Kabupaten Solok". Penelitian ini mengkaji tentang rasa perduli nagari Saniang Baka terhadap pembangunan kampung halaman yang terlihat dari hasil penelitiannya adalah besarnya kontribusi perantau terhadap kampung halamannya.

Penelitian ini juga, mengkaji tentang perantau. Namun, fokus kajian penulis berbeda dengan penelitian sebelumnya. Penulis memfokuskan pada kajian aspek bentuk peran perantau terhadap pembangunan daerah asal dan bentuk usaha perantau dalam menciptakan lapangan pekerjaan di daerah asal Galogandang.

\section{METODE PENELITIAN}

Penelitian ini menggunakan pendekatan kualitatif dengan metode studi kasus. Penelitian ini bersifat deskriptif, yaitu berusaha untuk menggambarkan dan menjelaskan secara terperinci tentang masalah yang akan diteliti. Informan dalam penelitian ini adalah wali nagari, kepala jorong, pengurus mesjid, penduduk (petani, ibu rumah tangga, pembuat/pengrajin gerabah dan batu bata), dan perantau dari daerah Jakarta dan Pasaman. Jenis data pada penelitian kualitatif ini ada dua yaitu data primer dan data sekunder. Unit analisis dalam penelitian adalah satuan tertentu yang diperhitungkan sebagai 
subjek penelitian. Teknik pengumpulan data yang digunakan dalam penelitian ini adalah obsevasi lapangan, wawancara, dan studi dokumentasi. Teknik analisa data dalam penelitian ini menggunakan teknik analisis interaktif dengan langkah-langkah pengumpulan data, reduksi data, display data dan penarikan kesimpulan. Lokasi penelitian ini dilakukan di Jorong Galogandang, Kabupaten Tanah Datar.

\section{BENTUK PERAN PERANTAU TERHADAP PEMBANGUNAN DI GALOGANDANG}

Kebutuhan manusia dipermukaan bumi terus berkembang, akibatnya secara alami ukuran kebutuhan manusia yang disediakan alam jumlahnya akan menjadi kecil. Manusia yang merupakan makhluk yang menolak keterbatasan dirinya dan keterbatasan alam lingkunganya dengan fikiran yang akan selalu mengimbangi pertumbuhan kebutuhan dengan segala kebutuhannya dengan membudayakan sumber daya lingkungan. Pada proses pembudayaan alam untuk mempertahankan ukuran yang telah diperoleh serta untuk meningkatkan lebih lanjut tidak jarang harus menghadapi kenyataan yang terbatas dari dirinya sendiri dan pada alam lingkunganya. Kenyataan tersebut tidak jarang menjadi penghambat usahanya (Sumaadja 1986). Menurut Sastropoetra bentuk peran ada delapan, salah satunya adalah bentuk peran sumbangan spontan dalam bentuk uang dan barang. Perspektif Coleman menyatakan bahwa teori sosial tidak hanya merupakan latihan akademis, tetapi harus dapat mempengaruhi kehidupan sosial melalui "intervensi" tersebut (Ritzer 2011), maksudnya adalah bagaimana seseorang dapat berfikir untuk melakukan suatu perubahan dengan adanya tekanan baik dari dalam diri maupun dari luar dirinya dalam bertindak. Berfikir dengan mempertimbngkan secara rasional tersebut merupakan ide pokok pikiran Celeman. Demikian halnya dengan masyarakat Galogandang yang pada akhirnya berfikir untuk mengganti usahanya dalam pemenuhan kebutuhan hidup dengan cara merantau, karena produksi dari lahan pertanian tidak mampu untuk memberikan penghasilan yang lebih.

Sehingga berdasarkan peran sosial masyarakat adalah serangkaian hak, kewajiban, harapan, norma, dan prilaku seseorang yang harus dihadapi dan dipenuhi. Terlihat jelas berdasarkan pengertian tersebut, bahwa ,masyarakat Galogandang terutama perantau dan pemerintahan daerah memiliki suatu kewajiban dalam memperhatikan perkembangan kampung halamannya. Baik partisipasi secara moril maupun materil, disini berarti perantau Galogandang memiliki suatu kewajiban sebagai jembatan oleh masyarakat yang masih berada dikampung untuk membantu dalam perkembangan pembangunan fisik dan non fisik.

Berdasarkan peran menurut (Sastropoetra, RA 1988), yang salah satunya adalah sumbangan spontan dalam bentuk uang dan barang merupakan sesuatu bentuk peran perantau Galogandang dalam memberikan apresiasi untuk pembangunan daerah asalnya. Hal tersebut terlihat dari pembangunan fisik yang telah ada terlihat dari partisipasi perantau Galogandang seperti mesjid, mushala, lapangan bola kaki, balai adat, sumber air bersih, kantor P3N, dan MDA, sedangkan pembangunan secara non fisik berupa beasiswa pendidikan atau berupa bantuan dalam bentuk uang sebagai penghargaan untuk anak-anak yang berprestasi tapi orang tuanya tidak mampu, beasiswa tersebut diberikan untuk tingkat SMP sampai PT (Perguruan Tinggi). Sumber dana pembangunan yang telah dilakukan di Galogandang diperoleh dari sumbangan perantau dan anggaran pembangunan daerah.

Pergaulan hidup harus dipandang sebagai kesatuan manusia, manusia dalam arti makhluk yang saling mencari hubungan kemasyarakatan. Ada ikatan golongan yang tidak erat dan ada juga ikatan golongan yang erat. Ada dua ikatan kelompok pergaulan hidup yaitu Gemenschaft dan Gesellscahft. Dengan demikian keikutsertaan perantau dalam memperhatikan kampung halamannya cukup besar karena sebagai dari rasa perduli dan memiliki rasa kekeluargaan yang tinggi untuk masyarakat Galogandang, tidak hanya secara pribadi melainkan juga secara kelompok perantau yang berada didaerah rantau. Bagaimana seperti yang telah dijelaskan sebelumnya perantau telah banyak menyumbang untuk pembangunan 
fisik, dimana perantau memberikan sumbangan dana kepada masing-masing pengurus bagian yang akan disumbangkan. Selain dari sumbangan yang sudah menjadi suatu kewajiban perantau ada juga sumbangan atas permintaan masyarakat kampung halaman Galogandang misalnya seperti pembangunan mesjid, dimana pengurus mesjid meminta tambahan dana untuk pembangunan tempat berwuhu' dimesjid juga meminta dari perantau.

Dalam masyarakat selamanya ada orang atau golongan orang yang bergantung kepada pertolongan dan kedermawanan orang lain. Pembentukan suatu organisasi pada masyarakat tentu tidak akan hilang dengan begitu saja, karena dengan terbentuknya suatu organisasi sosial pada masyarakat akan mempermudah akses penyatuan individu maupun kelompok agar mudah untuk bersatu dalam memajukan pembangunan baik fisik maupun pembangunan non fisik. Demikian halnya dengan masyarakat Galogandang yang berada dirantau juga memiliki organisasi, yang bertujuan untuk mengkoordinir masyarakat dirantau. Selain itu juga organisasi tersebut dibentuk agar memperkuat rasa kekeluargaan mereka dirantau. Organisasi tersebut bernama "IKAPGA", yaitu merupakan singakatan dari Ikatan Keluarga Perantau Galogandang. Masing-masing daerah rantau memiliki nama organisasi yang sama, hanya saja kata IKAPGA ditambah sesuai dengan nama daerah rantau. Namun nama organisasi perantau tersebut hanya ada apabila perantau Galogandang yang banyak pada suatu daerah rantau saja. Nama tersebut seperti IKAPGA JAYA (Ikatan Keluarga Perantau Galogandang Jakarta Raya) dan IKAPGA PASAMAN. Nama kedua organisasi itu yang sering disebut-sebut oleh masyarakat yang menetap di Galogandang, karena pada umumnya masyarakat Galogandang merantau ke dua daerah tersebut. Perantau untuk daerah lain juga ada tetapi tidak banyak sehingga sumbangan yang diberikan untuk Galogandang pun tidak begitu banyak.

Meskipun partisipasi masyarakat dalam membangun cukup besar, namun disini tentu tidak seutuhnya pembangunan yang ada dari perantau. Hubungan perantau yang terjalin baik dengan pemerintahan daerah juga cukup membantu untuk prioritas anggaran pembangunan. Dari beberapa daerah tujuan perantau Galogandang daerah Jakarta yang paling banyak menjadi tujuan utama didatangi bagi Galogandang.

\section{DAMPAK MERANTAU TERHADAP SOSIAL EKONOMI MASYARAKAT GALOGANDANG}

Dampak merantau terhadap kehidupan sosial ekonomi masyarakat Galogandang dapat dilihat secara fisik dan non fisik : Secara fisik Banyaknya masyarakat Galogandang yang memiliki keinginan dalam merubah perekonomiannya sehingga mendorong mereka untuk merantau. Keberhasilan dirantau selain berpengaruh terhadap kehidupan secara pribadi juga dapat berpengaruh terhadap kesejahteraan Nagarinya, karena semenjak masyarakat Galogandang bertambah banyak yang merantau pembangunan pun terlihat mengalami perkembangan meskipun mereka tidak menetap dikampung halamannya. Bangunan rumah-rumah perantau terlihat sudah berbeda dengan sebelumnya, meskipun dipkerkampungan tetapi bangunan rumahnys tidak kalah menariknya dengan bangunan yang ada dikota. Selain dari bangunan pribadi milik masyarakat Galogandang yang merantau, bangunan sarana dan prasarana di Galogandang pun turut menjadi perhatian para perantau. Bangunan umum seperti bak sumber air bersih yang disumbangkan perantau terhadap kampungnya sehingga mempermudah masyarakat Galogandang dalam memperoleh air karena telah dibuatkan saluran air bersih yang berasal dari air mata air yang sudah diolah oleh masyarakat.

Selain itu, ada lagi pembangunan mesjid Akbar Galogandang pembangunan mushala, pembangunan sekolah TPA (taman pendidikan AL-Qur'an). Sejak masyarakat Galogandang banyak yang merantau, pembangunan di kampung pun menjadi bangunan yang megah seperti yang ada di kota. Rumah-rumah penduduk yang bagus dan mewah, seperti perumahan yang ada dikota. Pembangunan mesjid yang sudah terlihat rapi dengan fasilitas yang ada sekarang tidak lagi sama dengan fasilitas yang ada dulu.

Selain dari pembangunan secara fisik, pembangunan secara non fisik juga ada 
yaitu seperti adanya program beasiswa dari perantau untuk anak yang berprestasi tetapi ekonomi keluarganya rendah beasiswa tersebut diberikan untuk tingkat sekolah SMP hingga Perguruan Tinggi. Bantuan beasiswa pendidikan dari perantau kurang dilirik oleh anak-anak yang masyarakat Galogandang, karena mereka lebih tertarik mengikuti jejak karib kerabat, dan saudaranya untuk pergi merantau. Beasiswa pendidikan yang diberikan perantau terhadap masyarakat Galogandang diberikan langsung untuk anak yang akan menerima beasiswa tersebut.

Beasiswa pendidikan merupakan salah satu dari bentuk bantuan perantau, satu lagi bantuan yang diberikan perantau yaitu bantuan uang tunai yang dikirim perantau untuk GAKIN (keluarga miskin). Uang tersebut dikirim melalui salah satu kerabat orang perantau yang dipercaya, lalu dibagikan untuk beberapa keluarga. Biasanya masing-masing keluarga mendapat Rp. 300.000-Rp. 500.000. Selain beasiswa dan dana bulanan untuk keluarga tidak mampu, ada juga sejenis pembekalan ilmu pengetahuan seperti memberikan penyuluhan tentang pertanian dengan memprioritaskan daerah sendiri karena hubungan baik antara organisasi perantau dengan pementerihan daerahnya.

Selain dari memberikan beasiswa untuk pendidikan anak Galogandang, perantau Galogandang juga memberikan suatu peluang kerja di rantau dengan cara membawa anak Galogandang yang tidak lagi sekolah ataupun yang tidak memiliki pekerjaan dikampung. Perantau mencarikan pekerjaan untuk orang yang mereka bawa dari kampung dan juga memberikan tumpangan tempat tinggal sampai orang yang dari kampung tersebut sudah bisa memiliki tempat tinggal sendiri.

Arus ke kota adalah gejala yang paling nyata dalam kehidupan sosial saat ini. Arus itu adalah hasil budaya pengaruh mempengaruhi antara desa dengan kota, yang mampu meleburkan pergaulan hidup yang kaku dan tradisonal. Maka makin cepat pertumbuhan masyarakat kota, makin besar juga lah pengaruh yang diterima oleh masyarakat desa. Terlihat jelas disini bahwa penarik dari kota sangat berpengaruh, apalagi peluang kerja dikota yang lebih bersifat heterogen.
Semakin banyak masyarakat Galogandang yang merantau, maka akan membawa perubahan kepada perekonomian masyarakat. Perantau Galogandang semakin terlihat didaerah rantau karena, apabila mereka mendapat musibah di rantau maka sesuai toko dan kegiatan yang lain harus dihentikan. Perantau Galogandang banyak yang tetap menjaga budaya daerah asalnya meskipun mereka bertahun-tahun hidup di kota seperti kota Jakarta. Masyarakat Galogandang banyak memilih merantau ke ibu kota Jakarta, karena banyak peluang kerja terutama sektor dagang. Perantau Galogandang memiliki suatu komitmen bersama untuk membangun Nagarinya, sehingga mereka juga memiliki kesepakatan untuk menyatukan suara dalam pulang ke kampung halamannya. Perantau Galogandang sepakat untuk pulang samasama sekaligus membuat acara yang dikenal dengan "alek nagari" yang merupakan seremonial adat, karena mereka pulang hanya dalam jangka waktu satu kali dalam waktu empat tahun (diluar kepentingan pribadi). Meskipun sudah lama bergaul dengan lingkungan kota dari segi bahasa, seni dan sosial budaya mereka tidak ada yang berubah.

Dari segi bahasa untuk perantau yang berada di Jakarta yang tidak mengalami perubahan logat berbicara, karena mereka tinggal di Jakarta dengan kelompok yang sama dimana sehari-hari mereka tetap menggunakan bahasa asli kampungnya. Perantau yang berada di daerah lain seperti Pasaman, dari segi bahasa mereka tetap menggunakan bahasa Minangkabau namun untuk logat berbicara mengalami perubahan, perantau yang berada di Pasaman yang lebih dominan.

Pembangunan yang terlihat jelas pada jorong Galogandang adalah pembangunan secara fisik. Hal tersebut dapat dilihat berdasarkan konsep pembangunan menurut (Budiman 2000), yaitu pembangunan dapat diartikan sebagai usaha untuk memajukan warga dan masyarakat terutama kemajuan pada aspek material. Oleh karena itu pembangunan untuk SDM (Sumber Daya Manusia) membutuhkan waktu yang lama untuk memetik hasilnya. Meningkatkan pendidikan masyarakat di Galogandang 
tersebut sedikit sulit, karena persepsi masyarakat terhadap pentingnya pendidikan yang tinggi masih kurang. hal tersebut ditunjukkan dengan semakin banyak masyarakat Galogandang yang memilih merantau. Oleh sebab itu masyarakat Galogandang memiliki pandangan bahwa kesuksesan menjadi seorang pedagang lebih baik daripada memiliki pendidikan yang tinggi.

\section{KESIMPULAN}

Masyarakat Galogandang yang berada memiliki organisasi, yang bertujuan untuk mengkoordinir masyarakat di rantau. Selain itu organisasi tersebut dibentuk agar memperkuat rasa kekeluargaan mereka dirantau. Organisasi tersebut bernama "IKAPGA", yaitu merupakan singakatan dari Ikatan Keluarga Perantau Galogandang.

Bangunan rumah-rumah perantau terlihat sudah berbeda dengan sebelumnya, meskipun dipkerkampungan tetapi bangunan rumahnys tidak kalah menariknya dengan bangunan yang ada dikota. Selain dari bangunan pribadi milik masyarakat Galogandang yang merantau, bangunan sarana dan prasarana di Galogandang pun turut menjadi perhatian para perantau. Bangunan umum seperti bak sumber air bersih yang disumbangkan perantau terhadap kampungnya sehingga mempermudah masyarakat Galogandang dalam memperoleh air karena telah dibuatkan saluran air bersih yang berasal dari air mata air yang sudah diolah oleh masyarakat.

Pembangunan secara non fisik seperti adanya program beasiswa dari perantau untuk anak yang berprestasi tetapi ekonomi keluarganya rendah. Selain beasiswa, ada lagi bentuk bantuan dana bulanan untuk keluarga tidak mampu, selain itu juga ada sejenis pembekalan ilmu pengetahuan seperti memberikan penyuluhan tentang pertanian dengan memprioritaskan daerah sendiri karena hubungan baik antara organisasi perantau dengan pementerihan daerahnya. Selain itu Perantau Galogandang juga memberikan suatu peluang kerja di rantau dengan cara membawa anak Galogandang yang tidak lagi sekolah ataupun yang tidak memiliki pekerjaan dikampung. Perantau mencarikan pekerjaan untuk orang yang mereka bawa dari kampung dan juga memberikan tumpangan tempat tinggal sampai orang yang dari kampung tersebut sudah bisa memiliki tempat tinggal sendiri.

\section{DAFTAR PUSTAKA}

Budiman, Arief. 2000. Teori Pembangunan Ketiga. Jakarta: PT Gramedia Pustaka Umum.

Fitriasi, Lasmian Sihombing. 2011. Kehidupan Sosial Ekonomi Perantau Minangkabau Di Kota Tarutung Kabupaten Tapanuli Utara. Padang.

Friedman, Marilyn M. (1992). Family Nursing. Theory \& Practice. 3/E. Debora Ina R.L. (1998) ( alih bahasa ). Jakarta: EGC

Naim, Mochtar. 1984. Merantau Pola Migrasi Suku Minangkabau. Yogyakarta: Gadjah Mada University Press.

Ritzer, George. 2011. Teori Sosiologi Modern. Jakarta: Kencana prenada media group.

Sastropoetra, RA, Santaso. 1988. Partisipasi, Komunikasi, Bentuk Peran Dan Pembangunan Masyarakat. Cet 6. Bandung: Alumni Bandung.

Sumaadja, nursid. 1986. Perspektif Sosial. Bandung: Penerbit alumni. 


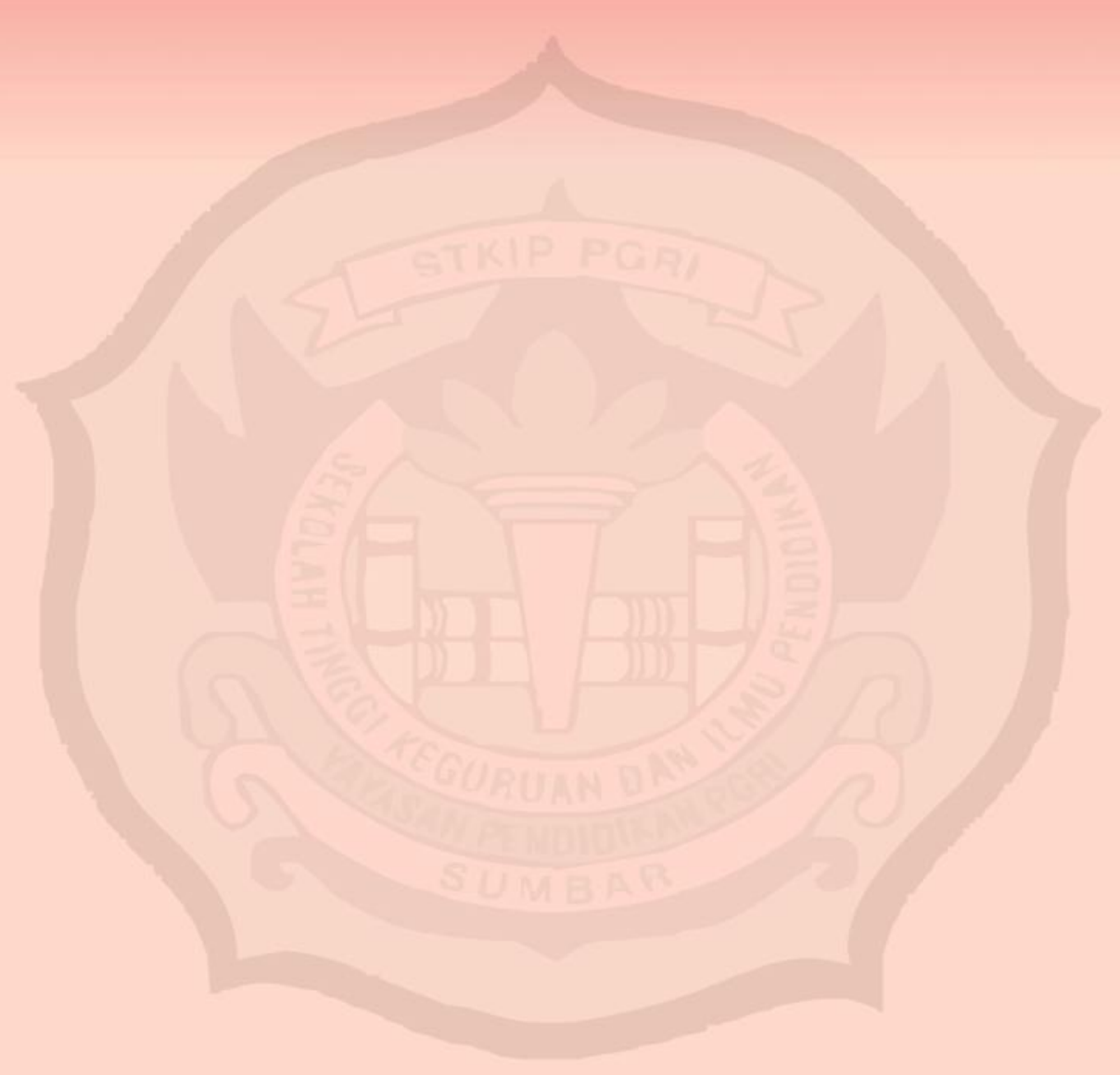

Penerbit :

Laboratorium Program Studi Pendidikan Sosiologi, STKIP PGRI Sumatera Barat Kampus STKIP PGRI, Jl. Gunung Pangilun, Padang, Sumatera Barat 